\title{
EKSISTENSI CADAR DITENGAH JILBAB SANTRI ${ }^{1}$ (Kajian Eksistensi Santri Bercadar Lingkungan Pondok Pesantren Di Jawa Timur)
}

\author{
Nurul Inayah ${ }^{1}$, Nawal Ika Susanti ${ }^{2}$ \\ Institut Agama Islam Darussalam Blokagung \\ Email: ninailzam2015@gmail.com¹,nika.girl22@gmail.com²
}

\begin{abstract}
The veil is an advanced version of the use of headscarves, in Islamic interpretation studies the arguments governing whether or not the use of veils is still under debate. However, the use of veils is actually in the community, bringing the consequences of rejection greater than the headscarf. Islamic boarding schools in East Java on average do not advocate and ban their santri from wearing veils. This is an interesting thing to be examined more deeply about how the santri still existed in the midst of his friends who were wearing headscarves. The findings in the field about the existence of veiled santri in the Islamic Boarding School Environment are that the first informant (Nur Aina) and the third Informant (Dewi Rahma) can still use the veil as a cover for the Islamic Shari'a wherever the informant is despite being the only veiled santri among santri veiled. While the second informant (Rahmatus Sholehah) could not exist among his friends due to the lack of support from the immediate family, criticism from the people closest to him, and differences in responses within the surrounding community made him unable to stay for Istiqomah using his veil.
\end{abstract}

Keywords: Veils, Headscarves, Existence, santri, Islamic Boarding School

\begin{abstract}
Abstrak
Cadar merupakan versi lanjutan dari penggunaan jilbab, dalam studi tafsir Islam dalil-dalil yang mengatur tentang wajib atau tidaknya penggunaan cadar masih dalam perdebatan. Namun, penggunaan cadar sebenarnya dimasyarakat, membawa konsekuensi penolakan lebih besar dari jilbab. Pondok pesantren yang ada di Jawa Timur rata-rata tidak menganjurkan dan melarang santrinya untuk bercadar. Hal inilah yang menarik untuk di kaji lebih dalam lagi tentang bagaimanakah santri tersebut tetap eksis ditengah-tengah temannya yang menggunakan jilbab. Hasil temuan dilapangan tentang eksistensi santri bercadar di Lingkungan Pondok Pesantren di dapat bahwa Informan pertama (Nur Aina) dan Informan ketiga (Dewi Rahma) dapat tetap eksis menggunakan cadar sebagai penutup aurat sesuai dengan syariat islam dimanapun informan berada meskipun menjadi satu-satunya santri bercadar diantara santri berjilbab. Sedangkan Informan kedua (Rahmatus Sholehah) tidak dapat eksis diantara teman-temannya dikarenakan tidak adanya dukungan dari keluarga terdekat, kecaman dari orangorang terdekatnya, dan perbedaan respon di dalam masyarakat sekitarnya membuatnya tidak dapat tetap untuk istiqomah menggunakan cadarnya.
\end{abstract}

Kata Kunci : Cadar, Jilbab, Eksistensi, santri, Pondok Pesantren

\footnotetext{
${ }^{1}$ Penelitian ini mendapatkan Dana Hibah dari Kemenag Tahun 2018
} 


\section{A. Pendahuluan}

Cadar sendiri merupakan versi lanjutan dari penggunaan jilbab, dalam studi tafsir Islam dalil-dalil yang mengatur tentang wajib atau tidaknya penggunaan cadar masih dalam perdebatan. Namun, penggunaan cadar sebenarnya dimasyarakat, membawa konsekuensi penolakan lebih besar dari jilbab. Selain persoalan stigma yang dilekatkan pada perempuan bercadar yakni aliran Islam fundamental (garis keras) yang sering dikaitkan juga dengan terorisme, cadar kini juga telah menghadapi penolakan teknis terutama yang berkaitan dengan pelayanan publik. Seperti kasus pelarangan mahasiswi bercadar di Universitas Islam Negeri Sunan Kalijogo Jogjakarta yang sempat menghebohkan dunia sosial media. Pelarangan juga dilakukan di Universitas Islam Negeri Sunan Ampel Surabaya (UINSA) walaupun tidak secara tertulis. Pada intinya pelarangan penggunaan cadar bagi mahasiswi perempuan lebih pada untuk menghilangkan hambatan dalam komunikasi antar civitas akademika. Seperti yang disampaikan oleh Rektor UINSA Prof. Abdul A'la.

Bukan hanya di Lingkungan Perguruan Tinggi Agama Islam, penggunaan cadar di lingkungan pondok pesantren pun memiliki beberapa perbedaan Respon. Respon dari santri maupun dari masyarakat sebenarnya cukup positif, rata-rata mereka tidak ada masalah dengan adanya perempuan bercadar di Pondok Pesantren mereka. Masyarakatpun yang tinggal disekitar pondok pesantren sebagian besar tidak keberatan dengan keberadaan santri yang bercadar. Beberapa ada yang menolak, karena masih berasumsi bahwa perempuan bercadar itu mencurigakan dan meresahkan.

Berdasarkan observasi sementara yang dilakukan oleh peneliti di beberapa Pondok Pesantren di Jawa Timur. Pondok pesantren yang ada di Jawa Timur ratarata tidak menganjurkan dan melarang santrinya untuk bercadar. Namun ada sebagian Pondok Pesantren yang memang memberi peraturan bahwa santrinya dianjurkan dan mewajibkan untuk bercadar. Di Pondok Pesantren Assuniyah Jember, semua santri di Pondok Pesantren ini diwajibkan menggunakan cadar, dan di Pondok Pesantren Dalwa Pasuruan mewajibkan santrinya bercadar sehingga tidak ada santri yang menggunakan jilbab. Sedangkan di Pondok Pesantren Al Qodiri Jember, ada larangan santri menggunakan cadar, Pondok 
Pesantren Al Islah Bondowoso juga melarang santrinya menggunakan cadar, tidak berbeda pula dengan Pondok Pesantren Darul Istiqomah Bondowoso juga melarang santrinya menggunakan cadar. Berbeda lagi yang ada di Pondok Pesantren Darussalam Blokagung Banyuwangi terdapat santri yang menggunakan cadar dan kesehariannya santri ini membaur dengan para santri di Pondok Pesantren Darussalam Timur.

Selain di Pondok Pesantren Darussalam Blokagung, di Pondok Pesantren Imam Syafii Genteng Banyuwangi juga tidak mewajibkan ataupun melarang santrinya menggunakan cadar atau tidak. Selain di daerah Banyuwangi, salah satu pondok pesantren di Jawa Timur yang tidak mewajibkan maupun melarang santrinya menggunakan cadar adalah Pondok Pesantren HM. Al Mahrusiyah Lirboyo Kediri. Meskipun tidak ada larangan menggunakan cadar di tiga pesantren tersebut, santri bercadar termasuk dalam komunitas yang minimum. Santri bercadar di Pesantren Darussalam Blokagung ada dua santri, santri bercadar di Pesantren HM. Al Mahrusiyah Lirboyo Kediri juga berjumlah satu santri saja. Sehingga mayoritas santri di kedua pesantren tersebut masih di dominasi oleh santri berjilbab. Hal inilah yang menarik untuk di kaji lebih dalam lagi tentang bagaimanakah santri bercadar tersebut tetap eksis ditengah-tengah temannya yang menggunakan jilbab.

\section{B. Landasan Teori}

\section{Pengertian Eksistensi}

Eksistensi berasal dari bahasa Inggris "exist" yang berarti ada, terdapat hidup atau dirasakan keberadaanya. Menurut kamus besar Bahasa Indonesia eksistensi adalah kehadiran, keberadaan yang mengandung unsur bertahan. Eksistensi menurut peneliti adalah keberadaan/kehadiran seseorang dalam lingkungan masyarakat yang memiliki keinginan untuk diakui keberadaannya khususnya dalam segi sosial. Karena pada hakikatnya manusia akan mengalami perubahan dari masa sekarang sampai masa yang akan datang baik dari segi perilaku, bahasa dan tindakan.

Menurut Smith (2003:21) mengatakan bahwa eksistensi diri merupakan suatu kondisi dimana seseorang dengan kemampuannya dapat menemukan makna 
dalam kehidupan. Makna merupakan eksistensi dari nilai- nilai batiniah yang paling utama dalam menjalani kehidupan. Adapun nilai-nilai batiniah yang dibicarakan adalah nilai-nilai mendasar seperti sikap menghormati manusia, sikap menghormati sesama dan perlunya bekerjasama serta bekerja bersama secara harmonis demi kebaikan bersama.

Berdasarkan teori-teori eksistensi yang dijelaskan diatas maka dapat dikatakan eksistensi diri adalah kebutuhan manusia akan arti. Individu meskipun harus tunduk pada kondisi- kondisi dari luar dirinya, namun pada dasarnya dalam memberikan tanggapan terhadap kondisi-kondisi tersebut individu bebas. Individu bebas mengambil sikap untuk menemukan arti hidup.

\section{Ciri-ciri Individu yang Memiliki Eksistensi Diri}

Menurut Frankl (1967:15-22) dan Smith (2003:54-57) menyatakan bahwa ciri- ciri individu yang memiliki eksistensi diantaranya: 1) Kesadaran diri yaitu kemampuan untuk mengenali kekuatan dan kelemahan diri sendiri, apa yang mampu dilakukan, dan bagaimana cara melakukannya. 2) Kepercayaan diri yaitu kemampuan individu untuk meilhat sisi positif dari suatu peristiwa. 3) Harga diri yaitu bagaimana individu memfokuskan pada orang yang dilayani atau individu bekerja. 4) Kesadaran akan mendesakan yaitu kesadaran mengenai pentingnya peran yang ada dalam dirinya untuk segera direalisasikan. 5) Kesadaran yang kuat akan misi pribadi yaitu visi tentang apa yang perlu dilakukan dan semangat serta fokus dalam melakukannya. 6) Daya tarik pribadi yaitu sesuatu yang menjadi daya tarik individu sehingga dapat mempengaruhi penilaian orang lain terhadap dirinya. 7) Kesadaran dan rasa hormat akan keunikan diri yaitu tidak membanding-bandingkan diri dengan orang lain, atau mengkuatirkan apa yang tidak dimiliki diri. Fokusnya adalah pada siapa dirinya. Konsistensi terhadap kehidupan yaitu tidak terombang- ambing dengan setiap ide atau peluang baru atau perubahan kejadian. 8) Ketenangan dan kedamaian yaitu tetap berkepala dingin meskipun sedang menghadapi banyak masalah.

Sedangkan pengalaman individu dalam menemukan eksistensi dirinya sendiri dalam kehidupan sehari-harinya, perlu diperhatikan karena bisa mempengaruhi faktot-faktor yang berpengaruh terhadap eksistensi individu tersebut. Menurut Frankl dikutip oleh Schutz (1991:145) ada tiga faktor yang mempengaruhi 
hakikat dari eksistensi menusia, yakni: Spiritualitas, Kebebasan dan Tanggung Jawab.

\section{Konsep Cadar dan Jilbab}

Cadar dalam Kamus Besar Bahasa Indonesia berarti kain penutup kepala atau muka (bagi perempuan). Dalam bahasa Arab cadar disebut dengan النقاب. Niqob bentuk jamaknya Nuquub. Dalam kamus Al-Munawwir Niqab berarti kain tutup muka. Dalam kamus Lisaanul Arab kata النقاب yaitu kain penutup wajah bagi perempuan hingga hanya kedua mata saja yang terlihat. Dari arti kata cadar di atas, dapat dipahami bahwa cadar adalah suatu nama yang diperuntukkan bagi pakaian yang berfungsi untuk menutup wajah bagi perempuan. Untuk memudahkan memahami perbedaan antara cadar dengan Jilbab dan Khimar perlu dibuat klasifikasi istilah beberapa pakaian yang digunakan perempuan muslimah. Beberapa peristilahan dalam busana muslimah, antara lain:

1. Jilbab, yaitu pakaian terusan panjang yang menutupi seluruh badan kecuali tangan, kaki dan wajah yang biasa dikenakan oleh para perempuan muslim. Penggunaan jenis pakaian ini terkait dengan tuntunan syariat Islam untuk menggunakan pakaian yang menutup aurat.

2. Hijab, yaitu dinding yang membatasi sesuatu dengan yang lain. Dinding ini bisa berupa tirai atau yang lainnya yang fungsinya untuk memisahkan antara majelis laki-laki dan majelis perempuan. Di kalangan masyarakat khususnya muslim menyebutnya sebagai pakaian untuk perempuan muslim yang sesuai dengan syariat dan menyebut penyandangnya dengan kaum muhajjabah (perempuan yang mengenakan hijab).

3. Khimar, berasal dari bahasa Arab yang bentuk jamaknya "khumur" yang berarti kerudung dan tidak identik dengan jilbab, karena kerudung hanya merupakan bagian yang tidak terpisahkan dari jilbab yang harus dikenakan perempuan muslim. Maka diperintahkan kepada perempuan muslim untuk menutupkan kain kerudungnya pada lengan, leher, perhiasan yang dipakai di telinga dan leher sampai menutupi dada.

Dari penjelasan masing-masing busana yang dipakai oleh perempuan muslimah di atas dapat dibedakan mana yang disebut sebagai cadar dan mana yang tidak. Dimana cukup jelas bahwa cadarlah satu-satunya busana muslimah 
yang pemakaiannya yaitu dengan menutup wajah hingga hanya mata saja yang terlihat.

\section{Metode Penelitian}

Penelitian ini merupakan penelitian dengan pendekatan metode kualitatif. Penelitian kualitatif ini nantinya akan dilakukan dengan pendekatan studi kasus, karena berangkat dari studi yang mendalam terhadap kasus-kasus tertentu. Penelitian ini dilakukan di Pondon Pesantren Darussalam Blokagung Banyuwangi dan Pondok Pesantren HM. Al Mahrusiyah Lirboyo Kediri, sebagai tempat tinggal sementara ketika menuntut ilmu bagi santri yang mengunakan cadar.

Untuk memperoleh data yang diperlukan dalam penelitian ini, maka peneliti menggunakan beberapa teknik pengumpulan data, yaitu: 1) Wawancara mendalam dilakukan kepada tiga Informan mahasiswi yang bercadar. Dua Informan dari Pondok Pesantren Darussalam Blokagung Banyuwangi dan satu Informan dari Pondok Pesantren HM. Al Mahrusiyah Lirboyo Kediri. 2) Partisipan Observation (Pengamatan Peran) pada dasarnya melakukan pengamatan dan terlibat langsung untuk mendapatkan kebenaran tentang kondisi riel santri bercadar. Observasi dilakukan dengan terjun langsung dalam kehidupan santri bercadar selama kurang lebih 15 hari. 3) Dokumentasi digunakan untuk memperkuat data yang diperoleh dari hasil wawancara dan observasi partisipan tentang eksistensi santri bercadar, dengan cara melihat bukti fisik yang ada dan berkaitan dengan kepentingan penelitian.

Pada penelitian ini informan sebagai sumber data primer dipilih dengan menggunakan purposive sampling dan sesuai dengan kriteria, yaitu : 1) Santri yang bercadar. 2) Menjadi santri pada salah satu Pondok Pesantren dimana santri berjilbab dan santri bercadar berada dalam satu Pondok Pesantren yang sama. Dan Informan yang di dapat adalah santri yang berada di Pondok Pesantren Darussalam Blokagung Banyuwangi dan Pondok Pesantren HM. Al Mahrusiyah Lirboyo Kediri. Selain itu untuk menjawab rumusan tentang interaksi dan respon santri bercadar, maka informan di dipilih pada pengasuh Pondok Pesantren dan santri berjilbab yang berinteraksi langsung dengan santri bercadar. Dalam penelitian ini data sekunder juga di ambil tentang sejarah berdirinya Pondon 
Pesantren Darussalam Blokagung Banyuwangi dan Pondok Pesantren HM. Al Mahrusiyah Lirboyo Kediri..

Analisis Data menurut Miles dan Huberman (1984) merupakan aktivitas dalam analisis data kualitatif dilakukan secara interaktif dan berlangsung secara terus menerus sampai tuntas, sehingga datanya jenuh. Aktivitas dalam analisis data yaitu reduksi data, penyajian data, dan penarikan kesimpulan (Sugiyono, 2015:246). Dalam proses analisis terdapat tiga komponen utama yang harus benar-benar dipahami oleh peneliti kualitatif. Tiga komponen tersebut adalah: 1) Reduksi Data. Mereduksi data berarti merangkum, memilih hal-hal yang pokok, memfokuskan pada hal-hal yang penting, dicari tema dan polanya. Hal-hal yang tidak penting dibuang untuk menghindari bias. 2) Penyajian data, bisa dilakukan dalam bentuk uraian singkat, bagan, hubungan antar kategori, dan sejenisnya. Denangan menyajikan data, maka akan memudahkan untuk memahami apa yang terjadi, merencanakan kerja selanjutnya berdasarkan apa yang telah difahami tersebut. 3) Penarikan Simpulan dan Verifikasi agar cukup mantap dan benarbenar bisa dipertanggungjawabkan. Kesimpulan yang dikemukakan pada tahap awal, didukung oleh bukti-bukti yang valid dan konsisten saat peneliti kembali ke lapangan mengumpulkan data, maka kesimpulan yang dikemukakan merupakan kesimpulan yang kredibel.

\section{Hasil}

\section{Identitas Informan}

Informan dalam penelitian ini diantaranya adalah santri yang menggunakan cadar di Lingkungan Pondok Pesantren Darussalam Blokagung yaitu Nur Aina Sheeromaa berusia 21 tahun yang berasal dari Thailand mahasiswi IAI Darussalam Blokagung Program Studi Tadris Bahasa Indonesia dan juga Rahmatus Sholehah yang berasal dari Rogojampi Indonesia yang merupakan mahasiswi IAI Darussalam Blokagung Program Studi Pendidikan Bahasa Arab sedangkan Informan yang berasal dari Pondok Pesantren HM Al-Mahrusiyyah Lirboyo Kediri yaitu Dewi Rahmah Septiyani berusia 22 tahun yang berasal dari Kediri yang merupakan mahasiswi IAIT Lirboyo Kediri Program Studi Akuntasi Syariah. Dalam penelitian ini, secara intensif wawancara dilakukan mendalam 
kepada ketiga Informan, selain wawancara mendalam, peneliti juga melakukan observasi dengan terjun langsung dalam kehidupan ketiga santri ini selama kurang lebih 15 hari untuk mengetahui bagaimanakah interaksi yang dilakukan oleh Informan di lingkungan Pondok Pessantren Darussalam Blokagung dan Pondok Pesantren HM Al-Mahrusiyyah Lirboyo Kediri. Untuk mengetahui respon dari pengasuh dan santri berjilbab terhadap keberadaan ketiga Informan ini maka Informan selanjutnya yang di wawancarai oleh peneliti adalah para pengasuh dan santri berjilbab di kedua pondok pesantren tersebut.

\section{Temuan Dilapangan}

Keberadaan seseorang yang berbaur dalam lingkungan masyarakat, dikarenakan ingin diakui, khususnya dalam segi sosial. Karena pada dasarnya manusia akan mengalami perubahan dari masa sekarang sampai masa yang akan datang baik dari segi bahasa, perilaku, tindakan. Santri bercadar yang sekaligus seorang mahasiswi di Perguruan Tinggi Agama Islam yang berbasis pesantren merupakan fenomena baru di dalam lingkungan Pondok Pesantren khususnya Pondok Pesantren Darussalam Blokagung dan Pondok Pesantren HM ALMahrusiyyah Lirboyo Kediri. Menariknya adalah bagaimana cara santri yang bercadar tersebut tetap eksis di tengah tengah perbedaan dengan teman-teman berjilbabnya. Informan sebagai seorang individu yang mempunyai suatu kebutuhan manusia akan arti dirinya sendiri harus tunduk pada situasi dari luar dirinya namun tetap memiliki kebebasan dalam mengambil sikap untuk menemukan arti hidupnya. seseorang dikatakan memiliki eksistensi terhadap dirinya sendiri jika memiliki ciri-ciri sebagai berikut:

\section{Kesadaran Diri}

Salah satu ciri seorang seseorang dapat dikatakan memiliki eksistensi terhadap dirinya sendiri jika seseorang tersebut mempunyai kesadaran diri akan kemampuannya untuk mengenali kekuatan dan kelemahan dirinya sendiri serta mampu untuk menunjukkan kekuatan dan mengatasi kelemahan yang dimilikinya untuk tetap eksis dengan makna hidupnya. Dari hasil wawancara dari ketiga Informan diketahui bahwa : Pada saat informan menunjukkan kekuatan dan kelemahannya, informan pertama (Aina) dan Informan ke 2 
(Rahma) mencoba untuk memotivasi diri sendiri bahwa semua yang dilakukan adalah yang terbaik. Untuk itu mereka tetap menggunakan cadar, apapun yang terjadi, seperti yang disampaikan oleh Aina dan Informan ke 3 (Dewi). Sedangkan Rahma masih harus memberikan pemahaman kepada orang-orang terdekatnya (keluarga) tentang cadar. Selain itu rahma juga memberikan pengertian bahwa cadar tidak akan mengubah pribadi, serta melakukan kesepakatan untuk mendapatkan restu orang tua.

\section{Kepercayaan Diri}

Seseorang dapat dikatakan memiliki eksistensi terhadap dirinya sendiri jika individu tersebut mempunyai kepercayaan diri akan kemampuannya untuk melihat sisi positif dari suatu peristiwa atau kejadian dalam hal ini adalah kemampuan Informan melihat sisi positif dari menggunakan cadar dalam berinteraksi sosial dengan lingkungan (khususnya santri yang berjilbab) dalam kehidupan sehari-hari. Dalam hasil wawancara ditemukan bahwa dengan menggunakan cadar ternyata santri yang tinggal bersama teman-teman santri yang berjilbab justru Menumbuhkan Rasa kepercayaan diri di dalam diri Informan, pada diri Ainna dan Dewi. Dimana Ainna Merasa lebih nyaman dengan bercadar, dan merasa tidak minder. Ainna sendiri juga merasa lebih terjaga dengan menggunakan cadar. Dewipun merasa lebih terjaga dengan menggunakan cadar serta lebih santai dalam menanggapi pandangan orang lain.

Namun berbeda dengan yang terjadi dengan Rahma, dengan adanya Banyak kecaman, merasa tidak ada dukungan sosial bagi dia, Rahma mengalami raasa berkecil hati dan akhirnya memakai masker sebagai pengganti cadar.

\section{Kesadaran akan Mendesakan}

Dikatakan memiliki eksistensi terhadap dirinya sendiri jika individu tersebut mempunyai kesadaran akan mendesakan. Kesadaran akan mendesakan yang dimaksud disini adalah kesadaran mengenai pentingnya peran yang ada dalam dirinya untuk segera direalisasikan. Dari hasil wawancara yang telah dilakukan, Ainna merasa untuk mensegerakan bercadar dan tetap istiqomah dia akan selalu menghadiri pengajian bersama komunitas mahasiswa Thailand yang ada di Jember. Untuk Dewi sendiri merasa yakin dengan menggunakan cadar setelah masuk ke Pondok Pesantren yang mewajibkan santrinya menggunakan cadar, 
dan dengan menggunakan cadar, Dewi marasa harus mampu memiliki prestasi. Ini berbeda dengan Rahma justru merasa kehilangan kepercayaan diri setelah menggunakan cadar karena tidak adanya dukungan dari keluarga, serta mendapat kecaman dari lingkungannya yang terdekat.

\section{Kesadaran Terhadap Misi Pribadi}

Dikatakan memiliki eksistensi terhadap dirinya sendiri jika individu tersebut mempunyai kesadaran terhadap misi pribadi. Kesadaran terhadap misi pribadi yang dimaksud disini adalah kesadaran mengenai pentingnya visi tentang apa yang perlu dilakukan dan semangat serta fokus dalam melakukannya. Setiap orang akan memiliki misi dan tujuan dalam melakukan sesuatu. Bagi Ainna yang bercadar memiliki misi hanya untuk menutup aurat serta untuk menjaga diri dan menjadi pembatas dalam berperilaku. Sedangkan Rahma memakai cadar hanya mengikuti teman, dia tidak memiliki misi khusus.

\section{Daya Tarik Pribadi}

Daya tarik pribadi yang dimaksud disini adalah sesuatu yang menjadi daya tarik individu sehingga dapat mempengaruhi penilaian orang lain terhadap dirinya. Bercadar ternyata mampu menjadi daya tarik tersendiri bagi orang lain. Dengan bercadar Ainna masih Mudah membaur dengan teman-teman berjilbab dan mampu berinteraksi dengan baik. Karena Ainna sendiri memiliki sifat terbuka dengan orang lain. Sedangkan dewi Sama seperti orang-orang pada umumnya, tidak sombong, terbuka dan ramah dan dewi lebih Mengikuti alur kehidupannya. Rahma sendiri sebenarnya juga memiliki daya tariknya dengan sifat yang mudah bergaul, tidak membedakan teman, sebagai pendengar yang baik dan peduli pada sekitarnya. Namun dengan bercadar Rahma tidak menjadi tidak percaya diri.

\section{Kesadaran Dan Rasa Hormat Akan Keunikan Diri}

Kesadaran dan rasa hormat akan keunikan diri yang dimaksud disini adalah tidak membanding-bandingkan diri dengan orang lain, atau mengkuatirkan apa yang tidak dimiliki diri. Fokusnya adalah pada siapa dirinya. Konsistensi terhadap kehidupan yaitu tidak terombang- ambing dengan setiap ide atau peluang baru atau perubahan kejadian. Setelah melakukan wawancara maka ditemukan bahwa : Informan pertama tidak membandingkan dirinya sendiri 
dengan orang lain dan sudah bisa fokus terhadap dirinya sendiri sehingga bisa dikatakan sudah konsisten terhadap pilihannya, Informan kedua tidak pernah membanding-bandingkan dirinya sendiri dengan orang lain namun masih belum bisa fokus kepada dirinya sendiri sehingga belum bisa konisten terhadap pilihannya. Sedangkan Informan ketiga tidak pernah membandingkan dirinya sendiri dengan orang lain tapi sudah merasa dia sedikit berbeda dengan orang lain serta memiliki kepercayaan kepada dirinya sendiri sehingga bisa dikatakan Informan ketiga sudah konsisten terhadap keputusan yang diambilnya.

\section{Ketenangan dan Kedamaian}

Ketenangan dan kedamaian yang dimaksud disini adalah tetap berkepala dingin meskipun sedang menghadapi banyak masalah. Dari wawancara maka dapat diketahui bahwa : Informan pertama dalam menyelesaikan masalah yang ada dengan cara mencari pokok permasalahannya terlebih dahulu sebelum mencari solusinya. Jika tidak menemukan solusinya maka ya sabar, ikhlas dan pasrah. Informan kedua juga tidak jauh berbeda, mencari pokok permasalahannya baru mencari solusinya dan dimusyawarahkan bersama apapun hasilnya. Dan Informan ketiga mencoba melihat kembali apa yang telah terjadi dan dimana letak kesalahannya lalu mencoba untuk memperbaikinya.

\section{E. Pembahasan}

\section{Eksistensi Santri Bercadar di Lingkungan Pondok Pesantren}

Eksistensi diri merupakan keadaan individu yang dapat membaur dalam lingkungan masyarakat dikarenakan ingin di akui keberadaan dirinya khususnya dalam segi sosial. Berdasarkan penyajian data di atas, maka dapat dianalisis eksistensi santri bercadar ditengah jilbab santri sebagai berikut:

Tabel 1 Analisis Eksistensi Santri Bercadar

\begin{tabular}{|l|l|l|}
\hline Informan & \multicolumn{1}{|c|}{$\begin{array}{c}\text { Faktor } \\
\text { Eksistensi diri }\end{array}$} & \multicolumn{1}{c|}{ Analisis dari data lapangan } \\
\hline Informan 1 & Kesadaran Diri & $\begin{array}{l}\text { Informan pertama sudah memiliki kesadaran diri } \\
\text { terhadap anjuran menutup aurat sesuai syariat Islam, } \\
\text { mendalami ilmu agama dengan menjalani sunnahNya } \\
\text { serta dengan menggunakan cadar lebih terjaga dari } \\
\text { pandangan laki-laki namun Informan pertama juga } \\
\text { menyadari kelemahan yang dimilikinya yaitu rasa } \\
\text { bimbang atas sikap orang di sekitarnya, untuk } \\
\text { mengatasi kekuatan dan kelemahan yang ada }\end{array}$ \\
\hline
\end{tabular}


Lanjutan Tabel 1

\begin{tabular}{|c|c|c|}
\hline Informan & $\begin{array}{c}\text { Faktor } \\
\text { Eksistensi diri }\end{array}$ & Analisis dari data lapangan \\
\hline & & $\begin{array}{l}\text { di dalam dirinya, Informan pertama memotivasi } \\
\text { dirinya sendiri untuk tetap menggunakan cadar apapun } \\
\text { yang terjadi. }\end{array}$ \\
\hline & $\begin{array}{l}\text { Kepercayaan } \\
\text { diri }\end{array}$ & $\begin{array}{l}\text { Informan pertama sudah dapat menumbuhkan rasa } \\
\text { percaya diri di dalam dirinya untuk tetap } \\
\text { menggunakan cadar }\end{array}$ \\
\hline & $\begin{array}{l}\text { Kesadaran akan } \\
\text { Mendesakkan }\end{array}$ & $\begin{array}{l}\text { Informan pertama berusaha untuk tetap istiqomah } \\
\text { menggunakan cadar. Beberapa hal yang dilakukan } \\
\text { Informan pertama untuk merealisasikannya antara lain } \\
\text { dengan mengikuti komunitas cadar serta mengikuti } \\
\text { pengajian. }\end{array}$ \\
\hline & $\begin{array}{l}\text { Kesadaran } \\
\text { Terhadap Misi } \\
\text { Pribadi }\end{array}$ & $\begin{array}{l}\text { Misi pribadi yang dimiliki oleh Informan pertama } \\
\text { adalah untuk lebih menutup aurat dan cadar dijadikan } \\
\text { sebagai batas dalam berperilaku. Sedangkan } \\
\text { kendalanya adalah sulit masuk dalam lingkungan } \\
\text { masyarakat dan santri berjilbab serta kesulitan dalam } \\
\text { berkomunikasi dikarenakan per-bedaan bahasa. }\end{array}$ \\
\hline & $\begin{array}{l}\text { Daya Tarik } \\
\text { Pribadi }\end{array}$ & $\begin{array}{l}\text { Informan pertama memiliki beberapa daya tarik } \\
\text { pribadi untuk tetap dapat diterima di lingkungan } \\
\text { dimanapun ia berada. Daya tarik pribadi tersebut } \\
\text { diantaranya memiliki kemampuan berinteraksi dengan } \\
\text { baik jika kesulitan menggunakan bahasa maka } \\
\text { menggunakan bahasa tangan untuk lebih mudah } \\
\text { dipahami, lebih mudah berbaur dengan santri berjilbab } \\
\text { dan bersifat terbuka dengan teman temannya. }\end{array}$ \\
\hline & $\begin{array}{l}\text { Kesadaran dan } \\
\text { Rasa Hormat } \\
\text { akan Keunikan } \\
\text { Dirinya }\end{array}$ & $\begin{array}{l}\text { Informan pertama tidak membandingkan dirinya } \\
\text { sendiri dengan orang lain dan sudah bisa fokus } \\
\text { terhadap dirinya sendiri sehingga bisa dikatakan sudah } \\
\text { konsisten terhadap pilihannya, }\end{array}$ \\
\hline & $\begin{array}{l}\text { Ketenangan dan } \\
\text { Kedamaian }\end{array}$ & $\begin{array}{l}\text { Informan pertama dalam menyelesaikan masalah yang } \\
\text { ada dengan cara mencari pokok permasalahannya } \\
\text { terlebih dahulu sebelum mencari solusinya. Jika tidak } \\
\text { menemukan solusinya maka ya sabar, ikhlas dan } \\
\text { pasrah. }\end{array}$ \\
\hline \multirow[t]{2}{*}{ Informan 2} & Kesadaran Diri & $\begin{array}{l}\text { Informan kedua sudah memiliki kesadaran diri } \\
\text { terhadap anjuran menutup aurat sesuai syariat Islam, } \\
\text { namun Informan kedua juga menyadari kelemahan } \\
\text { yang dimilikinya yaitu adanya penolakan dari } \\
\text { keluarganya dan juga kecaman orang-orang } \\
\text { terdekatnya, untuk mengatasi kekuatan dan kelemahan } \\
\text { yang ada di dalam dirinya, Informan kedua } \\
\text { memberikan pemahaman kepada orang-orang terdekat } \\
\text { tentang cadar, memberikan pengertian bahwa cadar } \\
\text { tidak akan mengubah pribadinya, dan melakukan } \\
\text { kesepakatan untuk mendapatkan restu orang tua. }\end{array}$ \\
\hline & $\begin{array}{l}\text { Kepercayaan } \\
\text { diri }\end{array}$ & $\begin{array}{l}\text { Informan kedua tidak dapat memunculkan rasa } \\
\text { percaya diri di dalam dirinya justru perasaan berkecil } \\
\text { hati semakin besar ketika Informan kedua } \\
\text { menggunakan cadarnya. }\end{array}$ \\
\hline
\end{tabular}

Jurnal Darussalam; Jurnal Pendidikan, Komunikasi dan Pemikiran Hukum Islam Vol. XI, No 1:182-198. September 2019. ISSN: 1978-4767 (Cetak), ISSN: 2549-4171(Online) Terakreditasi Nasional. SK. No.21/E/KPT/2018 


\section{Lanjutan Tabel 1}

\begin{tabular}{|c|c|c|}
\hline & $\begin{array}{l}\text { Kesadaran akan } \\
\text { Mendesakkan }\end{array}$ & $\begin{array}{l}\text { Informan kedua tidak dapat menjelaskan arti peran } \\
\text { dalam dirinya sehingga menimbulkan hilangnya } \\
\text { kepercayaan diri untuk tetap menggunakan cadar. }\end{array}$ \\
\hline & $\begin{array}{l}\text { Kesadaran } \\
\text { Terhadap Misi } \\
\text { Pribadi }\end{array}$ & $\begin{array}{l}\text { Informan kedua tidak memiliki misi pribadi, sejauh ini } \\
\text { menggunakan cadar dikarenakan ikut-ikutan dengan } \\
\text { teman-temannya yang bercadar. }\end{array}$ \\
\hline & $\begin{array}{l}\text { Daya Tarik } \\
\text { Pribadi }\end{array}$ & $\begin{array}{l}\text { Informan kedua memiliki beberapa daya tarik pribadi } \\
\text { untuk tetap dapat diterima di lingkungan dimanapun ia } \\
\text { berada. Daya tarik pribadi tersebut diantaranya mudah } \\
\text { bergaul dengan teman-temannya, tidak suka } \\
\text { membeda-bedakan teman, dan merupakan pendengar } \\
\text { yang baik }\end{array}$ \\
\hline & $\begin{array}{l}\text { Kesadaran dan } \\
\text { Rasa Hormat } \\
\text { akan Keunikan } \\
\text { Dirinya }\end{array}$ & $\begin{array}{l}\text { Informan kedua tidak pernah membanding-bandingkan } \\
\text { dirinya sendiri dengan orang lain namun masih belum } \\
\text { bisa fokus kepada dirinya sendiri sehingga belum bisa } \\
\text { konsisten terhadap pilihannya }\end{array}$ \\
\hline & $\begin{array}{l}\text { Ketenangan dan } \\
\text { Kedamaian }\end{array}$ & $\begin{array}{l}\text { Informan kedua juga tidak jauh berbeda, mencari } \\
\text { pokok permasalahannya baru mencari solusinya dan } \\
\text { dimusyawarahkan bersama apapun hasilnya }\end{array}$ \\
\hline \multirow[t]{5}{*}{ Informan 3} & Kesadaran Diri & $\begin{array}{l}\text { Informan ketiga sudah memiliki kesadaran diri } \\
\text { terhadap anjuran menutup aurat sesuai syariat Islam, } \\
\text { mendalami ilmu agama dengan menjalani sunnahNya } \\
\text { serta dengan menggunakan cadar lebih terjaga dari } \\
\text { pandangan laki-laki namun Informan ketiga tidak } \\
\text { dapat menyadari kelemahan dirinya sendiri, untuk } \\
\text { mengatasi kekuatan dan kelemahan yang ada di dalam } \\
\text { dirinya, Informan ketiga memotivasi dirinya sendiri } \\
\text { untuk tetap menggunakan cadar apapun yang terjadi. }\end{array}$ \\
\hline & $\begin{array}{l}\text { Kepercayaan } \\
\text { diri }\end{array}$ & $\begin{array}{l}\text { Informan ketiga sudah dapat menumbuhkan rasa } \\
\text { percaya diri di dalam dirinya untuk tetap } \\
\text { menggunakan cadar }\end{array}$ \\
\hline & $\begin{array}{l}\text { Kesadaran akan } \\
\text { Mendesakkan }\end{array}$ & $\begin{array}{l}\text { Informan ketiga memaknai bahwa dirinya sendiri } \\
\text { memiliki andil besar dalam menggunakan cadar. } \\
\text { Beberapa hal yang dilakukan Informan ketiga untuk } \\
\text { merealisasikannya antara lain dengan mengikut } \\
\text { kursus singkat, Pergi ke Pondok Pesantren yang } \\
\text { mewajibkan santrinya menggunakan cadar dan } \\
\text { meningkatkan prestasi yang dimiliki. }\end{array}$ \\
\hline & $\begin{array}{l}\text { Kesadaran } \\
\text { Terhadap Misi } \\
\text { Pribadi }\end{array}$ & $\begin{array}{l}\text { Misi pribadi yang dimiliki oleh Informan ketiga adalah } \\
\text { dengan menggunakan cadar dapat lebih menjaga diri } \\
\text { sendiri. Sedangkan kendalanya adalah tidak adanya } \\
\text { dukungan sosial terhadap wanita bercadar meskipun } \\
\text { begitu Informan ketiga berani bicara di depan umum } \\
\text { dan mengeluarkan pendapat selama jelas rujukannya } \\
\text { dan memilihmendengarkan ketika belum memiliki } \\
\text { rujukan yang jelas. }\end{array}$ \\
\hline & $\begin{array}{l}\text { Daya Tarik } \\
\text { Pribadi }\end{array}$ & $\begin{array}{l}\text { Informan ketiga memiliki beberapa daya tarik pribadi } \\
\text { untuk tetap dapat diterima di lingkungan dimanapun ia } \\
\text { berada. }\end{array}$ \\
\hline
\end{tabular}

Jurnal Darussalam; Jurnal Pendidikan, Komunikasi dan Pemikiran Hukum Islam Vol. XI, No 1:182-198. September 2019. ISSN: 1978-4767 (Cetak), ISSN: 2549-4171(Online) Terakreditasi Nasional. SK. No.21/E/KPT/2018 
Lanjutan Tabel 1

\begin{tabular}{|l|l|l|}
\hline & $\begin{array}{l}\text { Daya tarik pribadi tersebut diantaranya mengikuti alur } \\
\text { kehidupan. }\end{array}$ \\
\cline { 2 - 3 } & $\begin{array}{l}\text { Kesadaran dan } \\
\text { Rasa Hormat } \\
\text { akan Keunikan } \\
\text { Dirinya }\end{array}$ & $\begin{array}{l}\text { Informan ketiga tidak pernah membandingkan dirinya } \\
\text { sendiri dengan orang lain tapi sudah merasa dia sedikit } \\
\text { berbeda dengan orang lain serta memiliki kepercayaan } \\
\text { kepada dirinya sendiri sehingga bisa dikatakan } \\
\text { Informan ketiga sudah konsisten terhadap keputusan } \\
\text { yang diambilnya. }\end{array}$ \\
\cline { 2 - 3 } & $\begin{array}{l}\text { Ketenangan dan } \\
\text { Kedamaian }\end{array}$ & $\begin{array}{l}\text { Informan ketiga mencoba melihat kembali apa yang } \\
\text { telah terjadi dan dimana letak kesalahannya lalu } \\
\text { mencoba untuk memperbaikinya. }\end{array}$ \\
\hline
\end{tabular}

Sumber: Hasil Temuan di Lapangan. 2018

Berdasarkan hasil temuan dilapangan tentang eksistensi santri bercadar di Lingkungan Pondok Pesantren di dapat bahwa Informan pertama (Nur Aina) dan Informan ketiga (Dewi Rahma Septiyani) dapat tetap eksis menggunakan cadar sebagai penutup aurat sesuai dengan syariat islam dimanapun Informan berada meskipun menjadi satu-satunya santri bercadar ditengah-tengah santri yang memakai jilbab. Sedangkan Informan kedua (Rahmatus Sholehah) tidak dapat eksis ditengah-tengah perbedaan yang ada. Hal ini dapat disebabkan karena motif awal menggunakan cadar masih ikut-ikutan teman, selain itu yang mendasari untuk melepas cadarnya adalah tidak adanya dukungan dari keluarga terdekat, kecaman dari orang-orang terdekatnya, dan perbedaan stigma di dalam masyarakat sekitarnya membuatnya tidak dapat tetap untuk istiqomah menggunakan cadarnya.

\section{Konfirmasi Teori dengan Temuan di Lapangan}

Menurut Smith eksistensi diri merupakan suatu kondisi dimana seseorang dengan kemampuannya dapat menemukan makna dalam kehidupan. Sedangkan pandangan Frank mengatakan bahwa eksistensi diri adalah berarti menjadi manusia sepenuhnya, dimana individu semakin mampu mengatasi dirinya sendiri dan memberi tujuan hidup supaya menjadi manusia sepenuhnya. Peneliti menangkap Nur Aina dan Dewi Rahma Septiyani menciptakan makna dalam kehidupannya untuk tetap eksis dengan pilihannya menggunakan cadar, hal ini dapat dilihat dari ciri-ciri yang dimiliki oleh informan yang memiliki eksistensi diri seperti kesadaran diri yang dimiliki oleh kedua informan tentang memaknai cadar yaitu menutup aurat sesuai dengan syariat islam dan juga cadar dapat lebih 
menjaga informan dari pandangan laki-laki yang bukan muhrimnya, kedua informan juga menumbuhkan rasa kepercayaan diri di dalam dirinya untuk tetap menggunakan cadar dalam keadaan apapun, kedua informan juga memiliki kesadaran akan mendesakkan peran dari diri informan untuk tetap istiqomah dalam menggunakan cadar, kedua informan juga memiliki kesadaran akan misi pribadi sebagai seorang muslimah untuk menutup aurat sesuai syariah islam dan menjalankan sunnahnya, kedua informan memiliki daya tarik sendiri dan kesadaran terhadap keunikan dirinya sendiri untuk dapat tetap memaknai cadar sebagai pilihan dalam hidupnya serta kedua informan memiliki kemampuan untuk mengatasi masalah dan menyelesaiakn masalahnya untuk mewujudkan tujuan hidupnya.

Peneliti menangkap hal yang berbeda dari informan kedua yaitu Rahmatus Sholehah. Informan kedua memiliki beberapa ciri-ciri yang menunjukkan eksistensi dirinya seperti informan kedua memiliki kesadaran diri dalam memaknai cadar sebagai sebuah pilihan dalam hidupnya namun tidak dapat menumbuhkan rasa kepercayaan diri di dalam dirinya untuk tetap menggunakan cadar, kesadaran akan peran dalam dirinya juga belum muncul dalam diri informan kedua, informan kedua tidak memiliki misi pribadi dalam dirinya meskipun tidak memiliki kesadaran akan misi pribadi dalam hidupnya namun informan kedua menyadari daya tari dan keunikan yang ada dalam dirinya sendiri, serta informan kedua sudah dapat menggali masalahnya dan mencoba mencari penyelesaian masalahnya meskipun pada akhirnya masih belum dapat untuk istiqomah dengan pilihannya menggunakan cadar.

Berdasarkan hasil temuan dilapangan tentang eksistensi yang dimiliki oleh informan maka peneliti dapat mengatakan bahwa ketiga informan memiliki eksistensi diri sesuai dengan teori eksistensi diri dan ciri-ciri eksistensi diri yang telah dikemukan oleh Smith dan Frankl, meskipun salah satu dari informan tidak dapat eksis dengan pilihannya.

\section{F. Kesimpulan}

Berdasarkan hasil temuan dilapangan tentang eksistensi santri bercadar di Lingkungan Pondok Pesantren di dapat bahwa Informan pertama (Nur Aina) dan 
Informan ketiga (Dewi Rahma Septiyani) dapat tetap eksis menggunakan cadar sebagai penutup aurat sesuai dengan syariat islam dimanapun Informan berada meskipun menjadi satu-satunya santri bercadar ditengah-tengah santri yang memakai jilbab. Sedangkan Informan kedua (Rahmatus Sholehah) tidak dapat eksis ditengah-tengah perbedaan yang ada. Hal ini dapat disebabkan karena motif awal menggunakan cadar masih ikut-ikutan teman, selain itu yang mendasari untuk melepas cadarnya adalah tidak adanya dukungan dari keluarga terdekat, kecaman dari orang-orang terdekatnya, dan perbedaan stigma di dalam masyarakat sekitarnya membuatnya tidak dapat tetap untuk istiqomah menggunakan cadarnya.

\section{Daftar Pustaka}

Abidin, Zainal. 2007. Analisis Eksistensial. Jakarta: PT. Raja Grafindo Persada. Al-Ghazali, Syaikh Muhammad. Hukum Memakai Cadar Hingga Hak Istri Yang Ditalak Tiga. Jakarta: Mizania.

Al-Hasyimi, Muhammad Ali. 1997. Jati Diri Wanita Muslimah. Jakarta: Pustaka Al-Kautsar.

Ali, Muhammad bin Muhammad. 2008. Hijab Pakaian penutup Aurat Istri Nabi $S A W$. Jakarta: PT. Buku Kita.

Banan Muthohharoh Zain. 2016. Proses Pembentukan Identitas (Studi Kasus Mahasiswi bercadar di Kota Malang). Skripsi. Fakultas Psikologi Universitas Islam Negeri Maulana Malik Ibrahim Malang

Barik, Haya Binti Murabok al. 2001. Ensiklopedi Wanita Muslimah. Jakarta: Darul Falah.

Baron R.A \& Byrne, D. 2003. Psikologi Sosial. Edisi Kesepuluh. Jilid 1. Jakarta: Erlangga

Calvin, S. H dan Lindzey, G. 1993. Teori- teori kepribadian: Humansistik. Alih Bahasa: Iswanto. Kamisius: Yogyakarta.

Deaux \& Philogene. 2001. Representation of The Social: Bridging Theoritical Traditions. Massachusetts: Blackwell Publisher.

Enginer, Asyhar Ali. 2003. Pembebasan Perempuan. Terjemahan Agus Nuryanto, Yogyakarta: LKiS.

Frankl. V.E. 1967. Psychotherapy and Existentialsm: Selected papers on Logotherapy. A Touchstone book: Newyork.

Juliani, Reni. 2018. Stigmatisasi Mahasiswa Tentang Maraknya Mahasiswa Bercadar Di Kampus (Studi Kasus Pada Mahasiswa Fakultas Ilmu Sosial dan Ilmu Politik Universitas Teuku Umar Meulaboh Kabupaten Aceh Barat). Community: Volume 4, Nomor 1, April 2018 ISSN: 2477-5746.

Koeswara. 1992. Logoterapi:Psikoterapi Victor Fankl. Yogyakarta:Kanisius.

Ladin, Carmen Bin. 2006. Inside The Kingdom, Kisah Hidupku di Arab Saudi. Terjemahan M. Yusdi. Jakarta: Pustaka Alvabet. 
Muhsin, Sholahuddin. 2016. Islamic Radicalism in the Middle of Moderate Community (Phenomenological Perspective of Pesantren Al-muttaqin Sowan Kidul Jepara). The 3rd University Research Colloquium, ISSN 2407-9189.

Muthahhari, Murtadha. 2000. Wanita dan Hijab. Terjemahan. Nashib Mustafa. Jakarta: PT. Lentera Basritama.

Mulyani, Sri, Nur Fadjrih Asyik, and Andayani Andayani. 2007. Faktor-Faktor yang Mempengaruhi Earnings Response Coeficient pada Perusahaan yang Terdaftar di Bursa Efek Jakarta. Jurnal Akuntansi dan Auditing Indonesia 11.1

Nursalam, dan Syarifuddin. 2015. Persepsi Masyarakat Tentang Perempuan Bercadar, Jurnal Equilibrium Pendidikan Sosiologi Volume III No. 1 Mei 2015 ISSN e-2477-0221 p-2339-2401.

Papalia, dkk. 2008. Human Development (Psikologi Perkembangan). Jakarta: Kencana Prenada Media Group

Pematasari, Yulita Ayu dan Putra, Asaas. 2018. Identitas Diri Perempuan Muslim Bercadar di Kota Bandung (Studi Fenomenologi Pada Komunitas Niqab Squad Bandung). Volume 1, Nomor 1, September 2018 M/1440

Rahman, Alif Fathur dan Syafiq, Muhammad. 2017. Motivasi, Stigma dan Coping Stigma pada Perempuan Bercadar, Jurnal Psikologi Teori dan Terapan, Vol. 7, No. 2, 103-115, ISSN: 2087-1708

Ratri, Lintang. 2011. Cadar, Media, dan Identitas Perempuan Muslim. TOPIK UTAMA.

Rasyid, Lisa Aisiyah. Bukido, Rosdalina. 2018. Problemtika Hukum Cadar Dalam Islam: Sebuah Tinjauan Normatif-Historis, Jurnal Ilmiah Al-Syir'ah Vol. 16 No. 1 Tahun 2018 Institut Agama Islam Negeri (IAIN Manado).

Sarwono, S.W. 2006. Psikologi Remaja. Jakarta: PT. Raja Grafindo Persada.

Schwartz et al. 2000. Ego Identity Status, Identity Style, And Personal Expressiveness: An Empirical Investigation Of Three Convergent Constructs. Journal of adolescent Research, Vol. 15 No. 4 504-521

Shihab, M Quraish. 2004. Jilbab, Pakaian Wanita Muslimah: Pandangan Ulama Masa Lalu dan Cendekiawan Temporer. Jakarta: Lentera Hati.

Syaifullah, NU online, Jum'at, 9 Maret 2018 08:30. www.nu.or.id, diakses 19 Agustus 2018. 